\title{
How an Innovative Climate can motivate an Entrepreneur
}

\author{
Saeed Rashed Al Shehhi \\ University of Dubai \\ E-mail: 00000003562@ud.ac.ae \\ Kamarul Zaman Bin Ahmad \\ University of Dubai \\ E-mail: kbinahmad@ud.ac.ae
}

\begin{abstract}
This is a theoretical paper of a conceptual model whose primary aim is to test, how innovative climate, Perceived Net Desirability of Self Employment (NDSE), Tolerance for Risk (TR), and Perceived Feasibility (self-efficacy) of self-employment (SE), could affect self-employment intentions. The model also proposes how Psychological Climate Adjustment, Emotional stability, and Openness to experience, impacts perceptions of the innovative climate of organizations.
\end{abstract}

\section{Introduction}

The entrepreneur or self-employed person is one who begins a new business by taking on a risk that many people do not want to take, as many prefer to work for others. Obviously, by taking the risk, the returns will be higher, which is attractive to some. However having your own business is often associated with frustrations, uncertainty, risk-taking, failure and so on (Campbell, 1992). This has enabled researchers to concentrate on the motivational factors towards becoming an entrepreneur. Herron and Sopienza (1992) said: "because motivation plays an important part in the creation of new organizations, theories of organizational creation that fail to address this notion are incomplete." Also, Kuratko et al. (1997) stated that there is a lack of research on entrepreneurial motivation. On the other hand, this model of entrepreneurial motivation is also going to be merged with another model investigating on how Innovative Climate can play a big role in entrepreneurial motivation since innovation. Innovation can bring new ideas which can be developed into a business, however, at the same time, it will trigger people to look for opportunities to become an entrepreneur. This study looks at innovation climate, psychological climate adjustment, emotional stability, openness to experience and person-organization fit within the context of the UAE. Although previous studies on entrepreneurial motivation tested only undergraduate business students, we would improve it by testing people currently working as employees in UAE firms for their intentions to become an entrepreneur. Also, this study aims to provide the right lessons for the HR managers in UAE, be it private or public sectors, to select the bestfit employees who can enhance innovative climate which in return be motivated (or not) to be an entrepreneur.

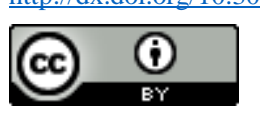

2523-6547 - Copyright: (C) 2017 The Authors. This is an open access article distributed under the terms of the Creative Commons Attribution License, which permits unrestricted use, distribution, and reproduction in any medium, provided the original author and source are credited. 


\section{Literature Review}

\section{Person-Organization Fit}

Person and environment are a close function of each other because the behavior of a person is affected by the environment and vice versa (Schneider, 1987). While Schneider focuses on organizational perspective towards their people, the attraction-selection-attrition (ASA) framework describe the effect of technology, structure, and large environment of organizations as outcomes not the behavior, personalities of people (Schneider, 1983, 1987). In short, organizations attract, select, and retains people who fit their purpose, so people behave the way they should do (Schneider, 1987). The fit between the organization and the person is a predictor for another result, such as job performance and turnover (Arthur et al., 2006). Dimensions of personenvironment fit are person-organization fit, person-group-fit, person-job fit, and person-vocation fit (Kristof, 1996). Because we focus on personnel selection (Arthur et al., 2006; Rynes et al., 2002) and employment decision-making, this study will use person-organization fit as one of the variables (Verquer et al., 2003). Person-organization fit (POF) can be defined as "the compatibility between people and organizations which occurs when: 1 . At least one entity provides what the other needs, 2 . They share similar fundamental characteristics, or 3. Both" (Kristof, 1996, p.45), but the efficacy of the POF fit starts when there is a congruence between the organization and personal values, interest, beliefs, and needs that shape through personal interest (Arthur et al., 2006). According to Schneider (1987) using attraction selection attrition (ASA) theory insist that persons are interested with organizations which meet their values and interests.

\section{Psychological climate adjustment}

The psychological climate theory persists that persons respond to a cognitive representation of an environment, not the environment itself (James and Sells, 1981), that means people interpret cognitively the organizational situation or "psychological climate" (James and Sells, 1981; Scott and Bruce, 1994). Signals received by people in the context of organizational expectations of behavior and behavioral performance is called the psychological climate adjustment (James et al.,1977). Individual behavior is regulated by the perspective of responding to high expectations which dictate the consequences of positive self-evaluations like self-satisfaction and self-pride (Scott and Bruce, 1994). Also psychological climate adjustment can represent how organizational environments are perceived and interpreted by individuals (James et al., 1978; Selmer,2005), and also depends on their experience with the organization (Koys and DeCotiis, 1991; Schneider, 1975). Also, it attributed with persons' emotional states, cognitive perceptions and personal traits variables (Ward and Kennedy, 1996). For that reason, psychological climate adjustment can be represented through employee's perceptions of their experience in that organization (Strutton et al.,1993). Also, it contributes towards the person's motivation to innovate and produce high job performance (James et al., 1977). Therefore, if employees are satisfied with their jobs, they will perform well (Anderzén and Arnetz, 1999).

\section{Personality traits}

Robbins (2005, p.103) defines personality traits as "enduring characteristics that describe an individual's behavior." More specifically, it is the sum of how an individual reacts to, and interacts with, others. Social researchers discovered that individual personality affects organizational outputs such as job performance, training success, turnover, self-rating, career development and leadership efficacy (Cabrera et al., 2003; Judge et al., 2000, 1999; Salgado,1997). Cabrera (2003) and Goldberg (1990, 1992) demonstrated that all personality measures could be integrated into five main factor models "The Big Five" that includes 1. Extroversion (extroverted, energetic, talkative, bold, active, assertive, adventurous, etc.) 2. Agreeableness (warm, kind, cooperative, unselfish, agreeable, trustful, generous, etc.)3. Conscientiousness (organized, responsible, conscientious, practical, thorough, hardworking, thrifty, etc.) 4. Emotional stability (calm, relaxed, at ease, not envious, stable, contented, unemotional, etc.) and 5. Openness to experience (intelligent, analytical, reflective, curious, imaginative, creative, sophisticated, etc.) and it is supported by empirical evidence (Digman, 1990; Goldberg, 1993; McCrae and Costa,1996; O’Connor, 2002).

\section{Innovative climate}

Without employees' innovations the organization will not survive for long (Van de Ven,1986, p.592). Kanter (1988) and Van (1986) suggested that psychological climate can stimulate innovation. An organization's 
innovative climate is the habit of bringing new ideas or behaviors to the company (Daft, 2007). Also, innovative climate starts with the understanding of the problem and the generation of solutions (Scott and Bruce, 1994, James et al. 1978, p.786). Usually, innovation occurs by following the steps of proposed development, evaluation, and testing which by then, the decision for implementation is made based on organizational requirements (Meyer and Goes, 1988). Also, positive climate can lead to improved innovation (Ekvall, 1994). Innovation is the key to organizational change that provides the vision of the past, present, and future (Ahmed, 1998). It is also attributed to openness and information exchange (Saleh and Wang 1993). So, positive, innovative climate may support company leaders for changes and their adaptation (Arvidsson et al., 2006).

\section{Person-organization fit (POF) and innovative climate}

POF explains the congruency between the person and the organization that happens when the company fulfills the person needs, interests and preferences (Kristof, 1996). Which means it can explain the relation between job selection and personality of an individual, regarding job information and organizational attractiveness (Carless, 2005; Dineen et al., 2002; Roberson and Collins, 2005). ASA (attraction-selection attrition) theory suggests that people are interested in specific companies and jobs that suit their interest and personalities (Schneider, 1987) which draw the relationship between job criteria and decision-making process for selection towards company attractiveness (Dineen et al., 2002; Ehrhart and Ziegert, 2005). Previous studies found out that innovative climate is not easy to maintain (Kristof-Brown et al., 2005; Scott and Bruce, 1994; Verquer et al., 2003; Wheeler et al., 2007). Holland (1976) proved that there is a similarity between career environments and the people that join them. An example of person-job fit is when employees mostly prefer joining companies which match their personality profile (Schneider, 1987, Tom,1971). Also, people see fit when they chose a company that improves their value or worth (Vroom, 1966). Schneider (1987), demonstrated that Holland's Theories, Vroom, Tom, and other abundant evidence showed that symmetrical persons with symmetrical personalities chose and behave the same which support team work and coherent cultural adaptivity, than just a specific job (Robbins, 2005).

\section{Psychological climate adjustment and innovative climate}

Psychological climate adjustment can be defined as "how employees perceive the organizational environment and interpret it about their well-being." It is about the relation between a person and their company requirements that increase involvement, and performance (Brown and Leigh, 1996). Psychological climate adjustment is constant over time and can be adhered to by employees in the same companies (Swift and Campbell, 1998). Employee's perception about creativity and change are supported by an organizational policy which reflects on the work procedures that increase their performance (Strutton et al., 1993; Swift and Campbell, 1998). Furthermore, both psychological climate adjustment and innovative climate are factors that shape person actions such as employee change related behavior (Burke and Litwin, 1992; Tierney, 1999) and change process model, employee cognitions (James and Jones, 1974). However concurrent studies proved that psychological climate predicts job satisfaction, job performance, work attitude, and organizational output (Carless, 2004; Parker et al., 2003). Psychological climate adjustment focused on the approach to problems and the attitude within the company (Grove and TorbiÖrn, 1985). The psychological climate is positively related to innovative climate base on the study by Ho (2009) in life insurance companies in Taiwan. Su's (2009) conceptual framework proposed the same.

\section{Person-organization fit (POF), psychological climate adjustment, and innovative climate}

POF is from the employees' perception, and this leads to a certain behavior at work (Rousseau, 1988). The psychological climate adjustment refers to various work-related factors such as "degree of supportive relationships and the degree to which innovation is promoted" (Schneider and Reichers, 1983; Tordera et al., 2008). Researchers showed that psychological climate adjustment might lead to an organizational innovative climate which is an openness to new ideas (González Roma et al., 2002; Koys and DeCotiis, 1991). Su's (2009) research result suggested that higher level of psychological climate adjustment will have a stronger positive moderating effect on the relationship between person-organization fit and an innovative climate.

2523-6547 - Copyright: (C) 2017 The Authors. This is an open access article distributed under the terms of the Creative Commons Attribution License, which permits unrestricted use, distribution, and reproduction in any medium, provided the original author and source are credited. 


\section{Person-organization fit (POF), personality traits, and innovative climate}

The leverage from personality and technical competence improve a person's creativity and innovation during the selection process (Harvey and Novicevic, 2002). Downes (2007) argued that a positive perception of the organization can lead to increased improvisation and innovation which helps to solve complex problems. So, the "Big Five" suggests that people who score high on agreeability will fit with the innovative climate. Robbins (2005), suggested that if an HR manager selects the right person (i.e., good fit), it will result in an improved organizational climate that will, in turn, lead to enhanced employee satisfaction, commitment, and turnover reduction. He also pointed out that HR managers are often interested to hire somebody who can adapt to changing situation in an organization, not who fit one particular type of job. However, Holland (1997) personality traits theory is the best to describe the fit between occupational requirements and individual personality traits. By analogy, we can match the employee's personality with an organization innovation climate and their commitment to adapt and change (Robbin, 2005). Moreover, matching persons and organization values will impact job satisfaction, commitment for improvement towards a more innovative climate (KristofBrown and Jansen, 2002). The word "Change" and Innovation are used interchangeably (Daft, 2007). Personality traits is an intervening variable which positively affects the relationship between POF and Innovation climate (Chao, 2007).

\section{Motivation and entrepreneurship}

Motivation has grown from the static content-oriented theories to dynamic process-oriented as Campbell et al. (1970) framework. The content theories try to find out something within people that "initiate, direct, sustain, and stop behavior," while process type theories demonstrate "how behavior is initiated, directed, sustained, and stopped." However, in the field of organizational psychology, research studies are concentrated on developing and testing content theories of motivation. Landy (1989) says that "data supportive of need theories have been infrequent; while damaging data are commonplace." This means that merely looking at personality to predict behavior is inaccurate. On the other hand, Mischel's (1968) mentioned that behavior is the result of the interaction between the individual and the situation (Shaver and Scott, 1991). By the mid-1960 process, theories were the favorite starting with Vroom's (1964) expectancy theory and were also supported by Locke's (1968) goal-sitting theory and finally by Bandura's (1977) Self-efficacy framework (Landy, 1989).

Entrepreneurship researches followed the same way, using the traits and characteristics rather than a process-oriented framework. For example, McClelland (1961) try to explain that achievements needs is a personality trait and it is common among entrepreneurs (Churchill and Lewis, 1986; Shaver and Scott, 1991). However, many researchers are testing the personality traits of entrepreneurs (Churchill and Lewis, 1986; Timmons, 1999), and the outcome is still inconclusive (Herron and Sapienza, 1992; Shaver and Scott, 1991), but still studies are continuing (Stewart et al., 1998). Furthermore the "pull" and "push" theory tries to explain the entrepreneurial motivation (Gilad and Levine (1986); the push theory says that persons are "pushed into entrepreneurship by negative external forces, such as job dissatisfaction, difficulty finding employment, insufficient salary, or inflexible work schedule", while the pull theory conclude that persons pulled into entrepreneurial scope because of their needs of independence, self-fulfillment, wealth, etc. One could argue that people are most likely to become an entrepreneur because of pull more than push actions (Keeble et al., 1992; Orhan and Scott, 2001). Several researchers tried to discover the situational and environmental elements which produce entrepreneurial behavior, such as job displacement, work experience, resources, and governmental influences. However, findings are not conclusive (Krueger et al.;2000; Sexton, 1987; Bird and Jelinek,1988; Jelinek and Litterer, 1994; MacMillan and Kartz, 1992). However, Vroom's (1964) Expectancy theory says that a person will choose a variety of behaviors when he understands which behavior will give him the best choice. Vroom also explained motivation as a product of expectancy, instrumentality, and valence; expectancy can be measured using perceived feasibility and self-efficacy to predict entrepreneurial intentions. Mone (1994) claimed that his model could predict entrepreneurial intentions, e.g., perceived desirability, outcome expectations, net benefits, and perceived utility.

\section{New process of modeling Motivation and entrepreneurship}

Some research suggests that entrepreneurs are motivated by the economic reward structure Baumol (1990). Campbell's (1992) economic decision theory is about the expected net present benefits of entrepreneurship compared to the gains of labor wage. If people expect that they will get more rewards by

2523-6547 - Copyright: (C) 2017 The Authors. This is an open access article distributed under the terms of the Creative Commons Attribution License, which permits unrestricted use, distribution, and reproduction in any medium, provided the original author and source are credited. 
being entrepreneurs than by being mere employees, then this would increase the desire for them to become entrepreneurs (Praag and Cramer (2001). Also, Levesque (2002) tested the choice between employment and self-employment using the utility-maximizing model which can change according to age, stage of life, etc. The three economic model centers on the risk in the choice of becoming an entrepreneur (Campbell, 1992; Praag and Cramer, 2001; Levesque et al., 2002). The profit of earning for self-employment is triple compared with employment, which means being risk-averse is not going to be a demotivating factor (Rees and Shah, 1986). Douglas and Shepherd (1999) stated that the more tolerant one is to risk, the bigger the attractiveness of being self-employed. Bird (1988) stressed on this framework. Also in the psychology of new business creation because of the deliberate choices provided by people, based on their assessment of the feasibility and desirability of being an entrepreneur (Ajzen and Fishbein, 1975;1980). Ajzen (1988) argued that the best theories to predict behavioral intention are the theories of reasoned action (TRA) and planned behavior (TPB). Kolvereid (1996) declared that the Ajzen (1991) theory is a good for explaining entrepreneurial intentions. Ajzen's TPB is widely accepted in much behavioral sciences and it is used empirically in a various study predicting and understanding behavioral intentions (Bansal, 2002; King, 2003; Masalu and Astrom, 2001; Rhodes, 2002). Shapero's (1982) theory of individual behavioral intentions is based on two pillars 1 . Perceived credibility (feasibility) and perceived desirability. Perceived desirability is the personal attractiveness of beginning a new business, while perceived feasibility is the measure of an individual's capability to start a business (Shapero and Sokol,1982). Moreover, Shapero added one more variable which is a propensity to act. Therefore, Shapero and Sokol (1982) and Krueger (1993) all have indicated that these three variables are related to entrepreneurial behavioral intentions which Erikson (2001) also agreed. Also, Azjen and Shapero's theories involved self-efficacy as part of feasibility, as a predictor of entrepreneurial intentions as well as Chen et al. (1998) who declared self-efficacy an important measure.

Therefore, borrowing from Shapero and Krueger's theories, we use self-efficacy to perceive feasibility (Campbell,1992; Praag and Cramer, 2001; Levesque et al., 2002). Also using Shapero and Krueger's calculated risk would be the best indicator of propensity (Campbell, 1992; Douglas and Shepherd, 1999, Praag and Cramer, 2001; Levesque et al., 2002). So, the model of entrepreneurial motivation uses three constructs: the perceived net desirability of self-employment (NDSE), perceived feasibility (self-efficacy) of self-employment (SE), and tolerance for risk (TR). Finally, this process-oriented framework of motivation to entrepreneurial is well-grounded and has support from previous literature (Jelinek and Litterer, 1994; MacMillan and Kartz, 1992; Sexton, 1987).

\section{The Conceptual Framework and Hypothesis}

The conceptual research framework will borrow from Feng (2011) empirical research study. Feng (2011) concluded that person-organization fit (POF) is positively related to organization's innovative climate. Results match previous studies, such as Kristof-Brown et al. (2005), Scott and Bruce (1994), Verquer et al. (2003), Wheeler et al. (2007), etc. Also, psychological climate adjustment is positivity related to organization's innovative climate as shown by Burke and Litwin (1992), Carless (2004), James and Jones (1974), Parker et al. (2003), Tierney (1999). That means that psychological climate adjustment and innovative climate play a big role in shaping employees behavior and can produce increased job satisfaction and performance. Moreover, psychological climate adjustment positively mediates the relationship between person-organization fit and the organization's innovative climate as per González-Roma et al. (2002), and Koys, DeCotiis (1991).

On the other hand personality traits are related to a firm's innovative climate (Robbins, 2005), and a firm must have employees whose personalities are agreeable to change if it is to have an innovative climate. Personality traits are also mediating the relationship between POF and organizations' innovative climate (Kristof-Brown and Jansen, 2002). However from the structural equation model (SEM) in that research it was discovered that psychological climate adjustment and personality traits do not have a direct relationship with person-organization fit (POE), and this will be investigated in this study too.

Gerry's (2005) empirical studies used Shapero and Krueger's theories where the study used selfefficacy as a proxy for perceived feasibility, and also borrowing from the economic models (Campbell, 1992; Praag and Cramer, 2001; Levesque et al., 2002). This shows that entrepreneurial motivation results from the difference between a person desire to work for other and self-employment. Taking calculated risk borrowed from Shapero and Krueger's propensity it is one of the best indicator (Gerry, 2005). Gerry (2005) also pointed that self-efficacy is the perceived desirability and benefits of self-employment in comparison to working for others. However, Gerry's (2005) empirical studies were conducted on students in the college. This proposed

2523-6547 - Copyright: (C) 2017 The Authors. This is an open access article distributed under the terms of the Creative Commons Attribution License, which permits unrestricted use, distribution, and reproduction in any medium, provided the original author and source are credited. 
research, on the other hand, will be conducted on employees working for companies, to check wither is there any intention for self-employment. Using Gerry (2005) and Feng (2011), the study will additionally test from the previous model if there is a relationship between the innovative climate and self-employment intentions.

H1: Person-organization fit is positively related to an organization's innovative climate.

H2: The individual's perception of a psychological climate adjustment is positively associated with an organization's innovative climate.

H3: A psychological climate adjustment moderates the relationship between person organization fit and an organization's innovative climate.

H4: Individual employees' emotional stability is positively associated with an organization's innovative climate.

H5: Individual employees' openness to experience is positively associated with an organization's innovative climate.

H6: Emotional stability moderates the relationship between person-organization fit and an organization's innovative climate.

H7: Openness to experience moderates the relationship between person-organization fit and an organization's innovative climate.

H8. There is a positive relationship between an individual's entrepreneurial self-efficacy (SE) and his or her intention to become an entrepreneur.

H9. There is a positive relationship between an individual's tolerance for risk (TR) and his or her intention to become an entrepreneur.

H10. There is a positive relationship between an individual's net desirability for self-employment (NDSE) and his or her intention to become an entrepreneur.

H11. An Innovative Climate is negatively associated with a Self-employment Intentions. 


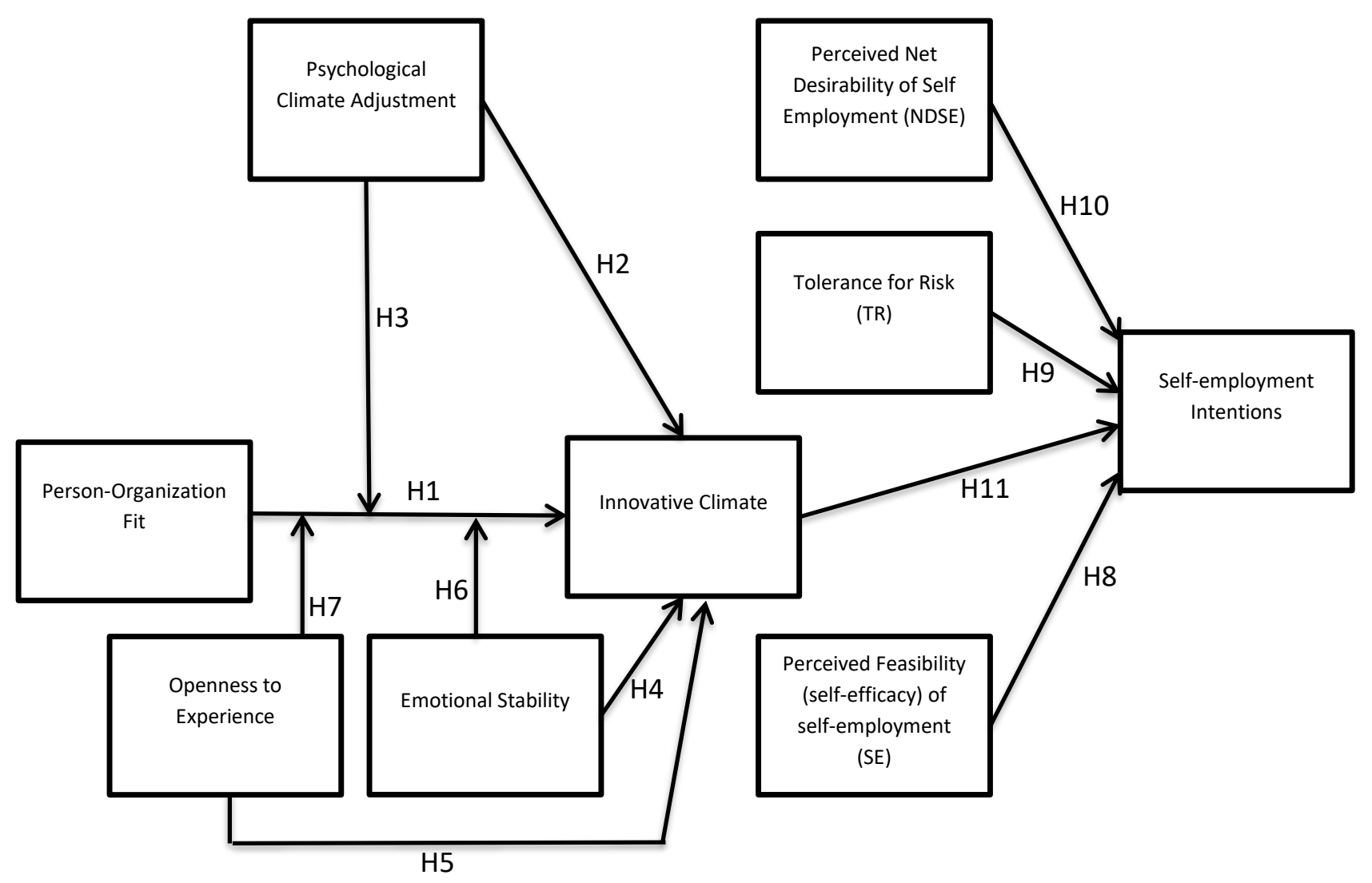

Figure 1 


\section{REFERENCES}

Ahmed PK (1998). Culture and climate for innovation. Eur. J. Innov. Manage., 1: 30-43.

Ajzen, I. (1988), Attitudes, Personalities and Behavior, Open University Press, Buckingham.

Ajzen, I. (1991), “The Ajzen theory of planned behavior”, Organizational Behavior and Human Decision Processes, Vol. 50 No. 2, pp. 179-211.

Ajzen, I. and Fishbein, M. (1980), Understanding Attitudes and Predicting Social Behavior, Prentice-Hall, Englewood Cliffs, NJ.

Anderzén I, Arnetz BB (1999). Psychophysiological reactions to international adjustment. Psychother. Psychosom., 68(2): 67-75.

Arthur W, Bell ST, Villado AJ, Doverspike D (2006). The use of person organization fit in employment decision making: an assessment of its criterion related validity. J. Appl. Psychol., 91(4): 786-801.

Arvidsson M, Johansson CR, Ek A, Akselsson R (2006). Organizational climate in air traffic control: innovative preparedness for implementation of new technology and organizational development in a rule governed organization. Appl. Ergon., 37(2): 119-129.

Bandura, A. (1977), Social Learning Theory, Prentice-Hall, Englewood Cliffs, NJ.

Bansal, H. (2002), "Investigating interactive effects in the theory of planned behavior in a service-provider switching context”, Psychology \& Marketing, Vol. 19 No. 5, pp. 407-19.

Baumol, W.J. (1990), "Entrepreneurship: productive, unproductive and destructive”, Journal of Political Economy, Vol. 98, pp. 893-921.

Bird, B.J. (1988), "Implementing entrepreneurial ideas: the case for intention", Academy of Management Review, Vol. 13 No. 3, pp. 442-53.

Bird, B. and Jelinek, M. (1988), "The operation of entrepreneurial intentions", Entrepreneurship Theory and Practice, Vol. 13 No. 2, pp. 21-9.

Brown SP, Leigh TW (1996). A new look at psychological climate and its relationship to job involvement, effort, and performance. J. Appl. Psychol., 81(4): 358-368.

Burke WW, Litwin GH (1992). A causal model of organizational performance and change. J. Manage., 18: 523545.

Cabrera A, Collins WC, Salgado JF (2003). Determinants of individual engagement in knowledge sharing. Int. J. Hum. Resource Manage., 17(2): 245-264.

Campbell, C.A. (1992), “A decision theory model for entrepreneurial acts”, Entrepreneurship Theory and Practice, Vol. 17 No. 1, pp. 21-7.

Campbell, J.P., Dunnette, M.D., Lawler, E.E. and Weick, K.E. (1970), Managerial Behavior, Performance, and Effectiveness, McGraw-Hill, New York, NY. Chen, C.C., Greene, P.G. and Crick, A. (1998), "Does entrepreneurial self-efficacy distinguish entrepreneurs from managers?", Journal of Business Venturing, Vol. 13 No. 4, pp. 295-316.

Carless SA (2004). Does psychological empowerment mediate the relationship between psychological climate and job satisfaction? J. Bus. Psychol., 18(4): 405-425.

Carless SA (2005). Person-job fit versus person-organization fit as predictors of organizational attraction and job acceptance intentions: a longitudinal study. J. Occup. Organ. Psych., 78(3): 411-429.

2523-6547 - Copyright: (C) 2017 The Authors. This is an open access article distributed under the terms of the Creative Commons Attribution License, which permits unrestricted use, distribution, and reproduction in any medium, provided the original author and source are credited. 
Chao CW (2007). The impact of personality traits as intervening variable on the relationship between personorganization fit and innovation climate. Taiwan: Dayeh University.

Churchill, N.C. and Lewis, V.L. (Eds) (1986), Entrepreneurship Research, Ballinger Publishing, Cambridge, MA. Douglas, E.J. and Shepherd, D.A. (1999), "Entrepreneurship as a utility maximizing response", Journal of Business Venturing, Vol. 15 No. 3, pp. 231-51.

Daft RL (2007). Understanding the theory and design of organization. China: Thomson South Western.

Digman JM (1990). Personality structure: emergence of the five-factor model. Annu. Rev. Psychol., 41: 417 440 .

Dineen BR, Ash SR, Noe RA (2002). A web of applicant attraction: person organization fit in the context of web-based recruitment. J. Appl. Psychol., 87(4): 723-734.

Downes M, Varner II, Musinski L (2007). Personality traits as predictors of expatriate effectiveness: a synthesis and reconceptualization. Rev. Bus., 27(3): 16-23.

Ehrhart KH, Ziegert JC (2005). Why are individuals attracted to organizations? J. Manage., 31(6): 901-919.

Ekvall G (1994). Ideas, organizational climate and management philosophy. Stockholm: Norstedts Förlag (in Swedish).

Erikson, T. (2001), "Revisiting Shapero: a taxonomy of entrepreneurial typologies", New England Journal of Entrepreneurship, Vol. 4 No. 1, pp. 9-15.

Feng-Hui Lee and Wann-Yih Wu, African Journal of Business Management Vol. 5(15), pp. 6415-6428, 4 August, 2011

Fishbein, M. and Ajzen, I. (1975), Belief, Attitude and Behavior: An Introduction to Theory and Research, Addison-Wesley, Reading, MA.

Gerry Segal, Dan Borgia, Jerry Schoenfeld, (2005) "The motivation to become an entrepreneur", International Journal of Entrepreneurial Behavior \& Research, Vol. 11 Issue: 1, pp.42-57

Gilad, B. and Levine, P. (1986), “A behavioral model of entrepreneurial supply”, Journal of Small Business Management, Vol. 24 No. 4, pp. 45-54.

Goldberg LR (1990). An alternative description of personality: the big five factor structure. J. Pers. Soc. Psychol., 59(6): 1216-1229.

Goldberg LR (1992). The development of markers of the big-five factor structure. Psychol. Assess., 4(1): 2642.

Goldberg LR (1993). The structure of phenotypic personality traits. Am. Psychol., 48: 26-34.

González-Roma V, Peiró JM, Tordera N (2002). An examination of the antecedents and moderator influences of climate strength. J. Appl. Psychol., 87: 465-473.

Grove CL, TorbiÖrn I (1985). A new conceptualization of intercultural Lee and Wu 6427 adjustment and the goals of training. Int. J. Intercult. Rel., 9(2): 205-233.

Harvey M, Novicevic MM (2002). The hypercompetitive global marketplace: the importance of intuition and creativity in expatriate managers. J. World Bus., 37: 127-138.

Herron, L. and Sapienza, H.J. (1992), "The entrepreneur and the initiation of new venture launch activities", Entrepreneurship Theory and Practice, Vol. 17 No. 1, pp. 49-55.

Ho PC (2009). The relationship between psychological climate adjustment and innovation climate: an empirical study of Taiwanese life insurance companies. Taiwan: Ling Tung University.

2523-6547 - Copyright: (C) 2017 The Authors. This is an open access article distributed under the terms of the Creative Commons Attribution License, which permits unrestricted use, distribution, and reproduction in any medium, provided the original author and source are credited. 
Holland JL (1976). Vocational preferences. In Dunnette M, ed. Handbook of industrial and organizational psychology. Chicago,McNally: Rand.

Holland JL (1997). Making vocational choices: a theory of vocational personalities and work environments. Odessa, FL: Psychological Assessment Resources Inc.

James LR, Hartman A, Stebbins MW, Jones AP (1977). Relationships between psychological climate and a vie model for work motivation. Pers. Psychol., 30(2): 229-254.

James LR, Hater JJ, Gent MJ, Bruni JR (1978). Psychological climate: implications from cognitive social learning theory and interactional psychology. Pers. Psychol., 31(4): 783-813.

James LR, Jones AP (1974). Organizational climate: a review of theory and research. Psychol. Bull., 81: 10961112.

James LR, Sells SB (1981). Psychological climate: theoretical perspectives and empirical research. In Mangussen D, ed. Toward a psychology of situation: an interactional perspective. NJ, Erlbaum: Hillsdale pp. 275-295.

Jelinek, M. and Litterer, J. (Eds) (1994), A Cognitive Theory of Organizations, Vol. 5, JAI Press, Greenwich, CT, pp. 3-42.

Judge TA, Bono JE, Locke EA (2000). Personality and job satisfaction: the mediating role of job characteristics. J. Appl. Psychol., 85(2): 237-249.

Judge TA, Higgins CA, Thoresen CJ, Barrick MR (1999). The big five personality traits, general mental ability, and career success across the life Span. Pers. Psychol., 52(3): 621-652.

Kanter R (1988). When a thousand flowers bloom: structural, collective, and social conditions for innovation in organization. In Staw BM, Cummings LL, eds. Research in organizational behavior. Greenwich, CT: JAI Press, pp. 169-211.

Keeble, D., Bryson, J. and Wood, P. (1992), "The rise and fall of small service firms in the United Kingdom", International Small Business Journal, Vol. 11 No. 1, pp. 11-22.

Kolvereid, L. (1996), "Prediction of entrepreneurial employment status: choice intentions", Entrepreneurship Theory and Practice, Vol. 21 No. 1, pp. 47-57.

Koys DJ, DeCotiis TA (1991). Inductive measures of psychological climate. Hum. Relat., 44(3): 49-58.

Kristof-Brown A, Zimmerman R, Johnson EC (2005). Consequences of individuals' fit at work: a meta-analysis of person-job, person organization, person-group, and person supervisor fit. Pers. Psychol., 58(2): 281-342.

Kristof-Brown AL, Jansen KJ (2002). A policy-capturing study of the simultaneous effects of fit with jobs, groups, and organizations. J.Appl. Psychol., 87(5): 985-993.

Kristof AL (1996). Person-organizational fit: an integrative review of its conceptualization, measurement, and implications. Pers. Psychol., 49(1): 1-49.

Krueger, N. (1993), “The impact of prior entrepreneurial exposure on perceptions of new venture feasibility and desirability”, Entrepreneurship Theory and Practice, No. Fall, pp. 5-19.

Krueger, N.F. Jr, Reilly, M.D. and Carsrud, A.L. (2000), "Competing models of entrepreneurial intentions", Journal of Business Venturing, Vol. 15 No. 5/6, pp. 411-32.

Kuratko, D.F., Hornsby, J.S. and Naffziger, D.W. (1997), “An examination of owner’s goals in sustaining entrepreneurship”, Journal of Small Business Management, Vol. 35 No. 1, pp. 24-33.

Landy, F.J. (1989), Psychology of Work Behavior, 4th ed., Brooks/Cole Publishing Company, Pacific Grove, CA.

2523-6547 - Copyright: (C) 2017 The Authors. This is an open access article distributed under the terms of the Creative Commons Attribution License, which permits unrestricted use, distribution, and reproduction in any medium, provided the original author and source are credited. 
Levesque, M., Shepherd, D.A. and Douglas, E.J. (2002), "Employment or self-employment? A dynamic utilitymaximizing model”, Journal of Business Venturing, Vol. 17 No. 3, pp. 189-210.

Locke, E.A. (1968), "Toward a theory of task motivation and incentives", Organizational Behavior and Human Performance, Vol. 3, May, pp. 157-89.

MacMillan, I. and Kartz, J. (1992), "Idiosyncratic milieux of entrepreneurial research", Journal of Business Venturing, Vol. 7 No. 1, pp. 1-8.

Masalu, R. and Astrom, A. (2001), "Predicting intended and self-perceived sugar restriction among Tanzanian students using the theory of planned behaviour", Journal of Health Psychology., Vol. 6 No. 4, pp. 435-45.

McClelland, D.C. (1961), The Achieving Society, Van Nostrand, Princeton, NJ.

McCrae RR, Costa PT (1996). Toward a new generation of personality theories: theoretical contexts for the five-factor model. In Wiggins JS, ed. The five factor model of personality: theoretical perspectives. New York: The Guilford Press.

Meyer AD, Goes JB (1988). Organizational assimilation of innovations: a multilevel contextual analysis. Acad. Manage. J., 31(4): 897-923.

Mischel, W. (1968), Personality and Assessment, Wiley, New York, NY.

Mone, M.A. (1994), "Comparative validity of two measures of self-efficacy in predicting academic goals and performance", Educational and Psychological Measurement, Vol. 54 No. 2, pp. 516-29.

Morley M (2007). Person-organizational fit. J. Manage. Psychol., 22(2): 109-117.

O'Connor BP (2002). A quantitative review of the comprehensiveness of the five-factor model in relation to popular personality inventories. Assessment, 9: 188-203.

Orhan, M. and Scott, D. (2001), "Why women enter into entrepreneurship: an explanatory model", Women in Management Review, Vol. 16 No. 5, pp. 232-43.

Parker CP, Baltes BB, Young SA, Huff JW, Altmann RA, Lacost HA, Roberts JE (2003). Relationship between psychological climate perceptions and work outcomes: a meta-analytic review. J. Organ. Behav., 24: 389-416.

Praag, C.M. and Cramer, J.S. (2001), "The roots of entrepreneurship and labor demand: individual ability and low risk", Economica, Vol. 68 No. 269, pp. 45-62.

Raad BD, Sullot E, Barelds DPH (2008). Which of the big five factors are in need of situational specification? Eur. J. Person., 22: 269-289.

Rees, H. and Shah, A. (1986), "An empirical analysis of self-employment in the UK”, Journal of Applied Econometrics, Vol. 1 No. 1, pp. 95-108.

Rhodes, R. (2002), "Extending the theory of planned behavior in the exercise domain: a comparison of social support and subjective norm", Research Quarterly for Exercise and Sport, Vol. 73 No. 2, pp. 193-200.

Robbins SP (2005). Organizational behavior. New Jersey: Pearson Printice Hall.

Roberson QM, Collins CJ (2005). The effects of recruitment message specificity on applicant attraction to organizations. J. Bus. Psychol., 19(3): 319-339.

Rousseau DM (1988). The construction of climate in organizational research. In Cooper CL, Robertson I, eds. International review of industrial and organizational psychology. London: Wiley.

Rynes SL, Brown KG, Colbert AE (2002). Seven common misconceptions about human resource practices: research findings versus practitioner beliefs. Acad. Manage. Exec., 16(3): 92-103.

2523-6547 - Copyright: (C) 2017 The Authors. This is an open access article distributed under the terms of the Creative Commons Attribution License, which permits unrestricted use, distribution, and reproduction in any medium, provided the original author and source are credited. 
Salgado JF (1997). The five factor model of personality and job performance in the European community. J. Appl. Psychol., 82(1): 30-43.

Schneider B (1975). Organizational climate: an essay. Pers. Psychol., 28(1): 447-479.

Schneider B (1983). An interactionist perspective on organizational effectiveness. In Whetten CK, ed. Organizational effectiveness: a comparison of multiple models. New York: Academic Press.

Schneider B (1987). The people make the place. Pers. Psychol., 40(3): 437-453.

Schneider B, Reichers AE (1983). On the etiology of climates. Pers. Psychol., 36: 19-39.

Scott SG, Bruce RA (1994). Determinants of innovative behavior: a path model of individual innovation in the workplace. Acad. Manage. J., 37(3): 580-607.

Selmer J (2005). Cross-cultural training and expatriate adjustment in China: western joint venture managers. Pers. Rev., 34(1): 68-84.

Sexton, D.L. (1987), “Advancing small business research: utilizing research from other areas”, American Journal of Small Business, Vol. 11 No. 3, pp. 25-31.

Sexton, D.L. and Vesper, K.H. (Eds), Encyclopedia of Entrepreneurship, Prentice-Hall, Englewood Cliffs, NJ.

Shapero, A. (1982), Social Dimensions of Entrepreneurship, Prentice-Hall, Englewood Cliffs, NJ.

Shapero, A. and Sokol, L. (1982), “The social dimension of entrepreneurship", in Kent, C.A.,

Shaver, K.G. and Scott, L.R. (1991), "Person, process, choice: the psychology of new venture creation", Entrepreneurship Theory and Practice, Vol. 16 No. 2, pp. 23-45.

Stewart, W.H. Jr, Watson, W.E., Carland, J.C. and Carland, J.W. (1998), “A proclivity for entrepreneurship: a comparison of entrepreneurs, small business owners, and corporate managers", Journal of Business Venturing, Vol. 14 No. 2, pp. 189-214.

Strutton D, Pelton LE, Lumpkin JR (1993). The relationship between psychological climate and salespersonsales manager trust in sales organizations. J. Pers. Sell. Sale. Manage., 13(4): 1-14.

Su SS (2009). An empirical study of the relationship among person organizational fit, psychological climate adjustment, and innovation climate of Chinese medicine industry of Taiwan. Taiwan: National Defense Management University. Swift CO, Campbell C (1998). Psychological climate: relevance for sales managers and impact on consequent job satisfaction. J. Market. Theor. Pract., 6(1): 27-37.

Tierney P (1999). Work relations as a precursor to a psychological climate for change: the role of work group supervisors and peers. J. Organ. Change Manage., 12(2): 120-133.

Timmons, J.A. (1999), New Venture Creation, 5th. ed., Irwin McGraw-Hill, Burr Ridge, IL.

Tom VR (1971). The role of personality and organizational images in the recruiting process. Organ. Behav. Hum. Perform., 6: 573-592.

Tordera N, González-Roma V, Peiró JM (2008). The moderator effect of psychological climate on the relationship between leader -member exchange (LMX) quality and role overload. Eur. J. Work Organ. Psychol., 17(1): 55-72.

Van de Ven AH (1986). Central problems in the management of innovation. Manage. Sci., 32(5): 590-607.

Verquer ML, Beehr TA, Wagner SH (2003). A meta-analysis of relations between person-organization fit and work attitudes. J. Vocat. Behav., 63(3): 473-489.

Vroom, V.H. (1964), Work and Motivation, Wiley, New York, NY.

2523-6547 - Copyright: (C) 2017 The Authors. This is an open access article distributed under the terms of the Creative Commons Attribution License, which permits unrestricted use, distribution, and reproduction in any medium, provided the original author and source are credited. 
Vroom VR (1966). Organizational choice: a study of pre- and post-decision processes. Organ. Behav. Hum. Perform., 1: 212-226.

Ward C, Kennedy A (1996). Crossing cultures: the relationship between psychological and socio-cultural dimensions of cross-cultural adjustment. In Pandey J, Sinha D, Bhawuk DPS, eds. Asian contributions to crosscultural psychology. New Delhi: Sage Publications.

Wheeler AR, Gallagher VC, Brouer RL, Sablynski CJ (2007). When person organization (mis) fit and (dis) satisfaction lead to turnover: the moderating role of perceived job mobility. J. Manage. Psychol., 22(2): 203219. 
